Prepared in cooperation with the Indiana Office of Community and Rural Affairs

\title{
Flood-Inundation Maps for the Wabash River at New Harmony, Indiana
}

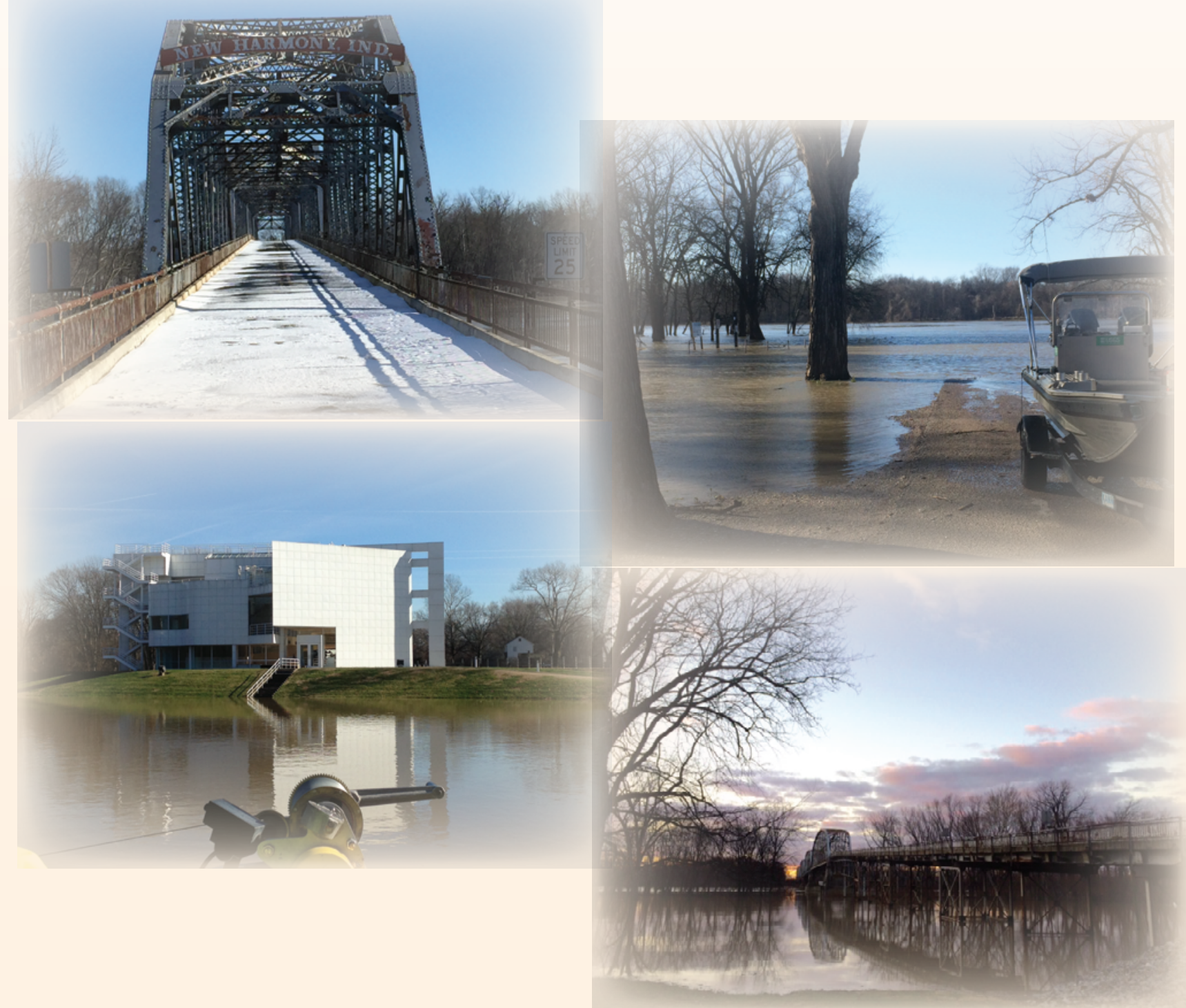

Scientific Investigations Report 2016-5119 


\section{Cover:}

Upper left: Bridge over the Wabash River at New Harmony, January 12, 2016. (Photo by Brian Moore, U.S. Geological Survey) Lower left: Flooding near New Harmony's Athenaeum. (Photo by Jason Thomas, U.S. Geological Survey)

Upper right: Boat photo is of the Wabash River at New Harmony, January 12, 2016. (Photo by Brian Moore, U.S. Geological Survey) Lower right: Sunset bridge photo is of the Wabash River at New Harmony, January 5, 2016. (Photo by Molly Lott, U.S. Geological Survey) 


\section{Flood-Inundation Maps for the Wabash River at New Harmony, Indiana}

By Kathleen K. Fowler

Prepared in cooperation with the

Indiana Office of Community and Rural Affairs

Scientific Investigations Report 2016-5119 


\section{U.S. Department of the Interior SALLY JEWELL, Secretary}

\section{U.S. Geological Survey Suzette M. Kimball, Director}

\section{U.S. Geological Survey, Reston, Virginia: 2016}

For more information on the USGS - the Federal source for science about the Earth, its natural and living resources, natural hazards, and the environment—visit http://www.usgs.gov or call 1-888-ASK-USGS.

For an overview of USGS information products, including maps, imagery, and publications, visit http://store.usgs.gov.

Any use of trade, firm, or product names is for descriptive purposes only and does not imply endorsement by the U.S. Government.

Although this information product, for the most part, is in the public domain, it also may contain copyrighted materials as noted in the text. Permission to reproduce copyrighted items must be secured from the copyright owner.

Suggested citation:

Fowler, K.K., 2016, Flood-inundation maps for the Wabash River at New Harmony, Indiana: U.S. Geological Survey Scientific Investigations Report 2016-5119, 14 p., http://dx.doi.org/10.3133/sir20165119.

ISSN 2328-0328 (online) 


\section{Acknowledgments}

The author wishes to thank the U.S Army Corps of Engineers-Louisville District for cooperation in the funding for the operation and maintenance of the streamgage used for this study. Special thanks are given to the Indiana Office of Community and Rural Affairs for their cooperation in this study and to the National Weather Service for their continued support of the U.S. Geological Survey flood-inundation mapping initiative. 



\section{Contents}

Abstract Introduction
Purpose and Scope
Study Area Description
Previous Studies
Creation of Flood-Inundation Map Library
Computation of Water-Surface Profiles
Hydrologic Data.
Hepographic and Bathymetric Data
Development of Water-Surface Profiles
$\quad$ Flood-Inundation Map Delivery
Disclaimer for Flood-Inundation Maps
Uncertainties and Limitations Regarding Use of Flood-Inundation Maps




\section{Figures}

1. Map showing location of the study reach for the Wabash River at New Harmony, Indiana, U.S. Geological Survey streamgage 03378500 and National Weather Service forecast site

2. Map showing location of high-water marks near New Harmony, Indiana, from the flood of April 27-28, 2013, and estimated area of inundation corresponding to a stage of 20.54 feet at the U.S. Geological Survey streamgage 03378500 .

3. Map showing direction of flow in the flood plain and estimated flood-inundation area for the Wabash River at New Harmony, Indiana, corresponding to a stage of 17.0 feet at the U.S. Geological Survey streamgage 03378500

4. Map showing direction of flow in the flood plain and estimated flood-inundation area for the Wabash River at New Harmony, Indiana, corresponding to a stage of 25.4 feet at the U.S. Geological Survey streamgage 03378500

\section{Tables}

1. U.S. Geological Survey streamgage information for the Wabash River at New Harmony, Indiana.

2. Coordinated discharges for selected annual exceedance probabilities for the Wabash River at New Harmony, Indiana.

3. Estimated discharges for corresponding stages and water-surface elevations at U.S. Geological Survey streamgage 03378500 used in the hydraulic model of the Wabash River at New Harmony, Indiana.

4. Calibration of hydraulic model to target water-surface elevations at the U.S. Geological Survey streamgage on the Wabash River at New Harmony, Indiana (station 03378500)

5. Calibration of hydraulic model to water-surface elevations at selected locations along the Wabash River, New Harmony, Indiana, for the flood of April 27-28, 2013 


\section{Conversion Factors}

Inch/Pound to International System of Units

\begin{tabular}{lcl}
\hline \multicolumn{1}{c}{ Multiply } & By & \multicolumn{1}{c}{ To obtain } \\
\hline foot $(\mathrm{ft})$ & Length & meter $(\mathrm{m})$ \\
mile $(\mathrm{mi})$ & 0.3048 & kilometer $(\mathrm{km})$ \\
\hline & 1.609 & \\
\hline square mile $\left(\mathrm{mi}^{2}\right)$ & Area & square kilometer $\left(\mathrm{km}^{2}\right)$ \\
\hline & 2.590 & \\
\hline cubic foot per second $\left(\mathrm{ft}^{3} / \mathrm{s}\right)$ & Flow rate & cubic meter per second $\left(\mathrm{m}^{3} / \mathrm{s}\right)$ \\
\hline & 0.02832 & meter per kilometer $(\mathrm{m} / \mathrm{km})$ \\
\hline foot per mile $\left(\mathrm{ft} / \mathrm{mi}^{2}\right)$ & Hydraulic gradient & \\
\hline
\end{tabular}

Vertical coordinate information is referenced to either (1) stage, the height above an arbitrary datum established at a streamgage or (2) elevation, the height above North American Vertical Datum of 1988 (NAVD 88).

Horizontal coordinate information is referenced to the North American Datum of 1983 (NAD 83). 



\title{
Flood-Inundation Maps for the Wabash River at New Harmony, Indiana
}

\author{
By Kathleen K. Fowler
}

\section{Abstract}

Digital flood-inundation maps for a 3.68-mile reach of the Wabash River extending 1.77 miles upstream and 1.91 miles downstream from streamgage 03378500 at New Harmony, Indiana, were created by the U.S. Geological Survey (USGS) in cooperation with the Indiana Office of Community and Rural Affairs. The flood-inundation maps, which can be accessed through the USGS Flood Inundation Mapping Science Web site at http://water.usgs.gov/osw/flood_inundation/, depict estimates of the areal extent and depth of flooding corresponding to selected water levels (stages) at the USGS streamgage at Wabash River at New Harmony, Ind. (station 03378500). Near-real-time stages at this streamgage may be obtained from the USGS National Water Information System at http://waterdata.usgs.gov/ or the National Weather Service (NWS) Advanced Hydrologic Prediction Service at http:// water.weather.gov/ahps/, which also forecasts flood hydrographs at this site (NHRI3).

Flood profiles were computed for the stream reach by means of a one-dimensional step-backwater model. The hydraulic model was calibrated by using the most current stage-discharge relations at the Wabash River at New Harmony, Ind., streamgage and the documented high-water marks from the flood of April 27-28, 2013. The calibrated hydraulic model was then used to compute 17 water-surface profiles for flood stages at approximately 1-foot intervals referenced to the streamgage datum and ranging from 10.0 feet, or near bankfull, to 25.4 feet, the highest stage of the stage-discharge rating curve used in the model. The simulated water-surface profiles were then combined with a geographic information system digital elevation model (derived from light detection and ranging (lidar) data having a 0.98 -ft vertical accuracy and 4.9-ft horizontal resolution) to delineate the area flooded at each water level.

The availability of these maps along with Internet information regarding current stage from the USGS streamgage at Wabash River at New Harmony, Ind., and forecasted stream stages from the NWS will provide emergency management personnel and residents with information that is critical for flood response activities such as evacuations and road closures, as well as for post-flood recovery efforts.

\section{Introduction}

The town of New Harmony, Indiana, is a community in Posey County with an estimated population of 789 (U.S. Census Bureau, 2010). New Harmony and the surrounding area have experienced flooding numerous times, most recently in 2008, 2011, and 2013. Most of the flood damages in the New Harmony area occurred along the Wabash River, which flows on the western side of the town. The Wabash River forms the western boundary of Posey County and is the boundary between Indiana and Illinois. Because the river has meandered over time, the boundary between the two states has shifted. During major floods, some evacuations are necessary in low areas on the northern and western sides of the town, as well as the surrounding rural community. As the stage rises, many areas of the town are under water, and some local roads are impassable. In addition, agricultural lands surrounding the town have the potential for flooding when embankments are overtopped. Flood plains along the river are moderately developed and contain a mix of residential, commercial, and agricultural areas.

Prior to the availability of the flood-inundation maps in this report, emergency responders in New Harmony relied on several information sources to make decisions on how to best alert the public and mitigate flood damages. One source is the Federal Emergency Management Agency (FEMA) flood insurance study (FIS) for Posey County (Federal Emergency Management Agency, 2007). The FEMA FIS examines the unincorporated areas of the county and does not cover New Harmony specifically. A second source of information is the U.S. Geological Survey (USGS) streamgage Wabash River at New Harmony, Ind. (station 03378500), for which current (U.S. Geological Survey, 2014a) and historical (U.S. Geological Survey, 2014b) water levels (stage) and discharges can be obtained. A third source is the National Weather Service (NWS) Advanced Hydrologic Prediction Service (AHPS) Web site http://water.weather.gov/ahps2/hydrograph. php?wfo=pah\&gage $=$ nhri3, which issues forecasts of stage at the USGS streamgage Wabash River at New Harmony (National Weather Service, 2014a).

Although the current stage at a USGS streamgage is particularly useful for residents in the immediate vicinity of a 
streamgage, it is of limited use to residents farther upstream or downstream because the water-surface elevation is not constant along the entire stream reach. Knowledge of a water level at a streamgage is difficult to translate into depth and areal extent of flooding at points distant from the streamgage. One way to address these informational gaps is to produce a library of flood-inundation maps that are referenced to the stages recorded at the USGS streamgage. By referring to the appropriate map, emergency responders can discern the severity of flooding (depth of water and areal extent); identify roads that are, or will soon be, flooded; and make plans for notification or evacuation of residents in harm's way for some distance upstream and downstream from the streamgage. In addition, the capability to visualize the potential extent of flooding has been shown to motivate residents to take precautions and heed warnings that they previously might have disregarded. In 2013-15, the USGS, in cooperation with the Indiana Office of Community and Rural Affairs, conducted a project to produce a library of flood-inundation maps for the Wabash River at New Harmony.

\section{Purpose and Scope}

This report describes the development of a series of estimated flood-inundation maps for the Wabash River at New Harmony, Ind., and identifies where on the Internet the maps can be accessed and ancillary data (geographic information system flood polygons and depth grids) can be downloaded. Internet users can select estimated inundation maps that correspond to (1) flood stages at streamgage 03378500 and (2) the NWS forecasted stages at the NWS site NHRI3. The scope of the study was limited to the Wabash River reach extending 1.77 miles (mi) upstream and $1.91 \mathrm{mi}$ downstream from streamgage 03378500 at the State Road 66 bridge (fig. 1).

The flood-inundation maps were produced for flood levels referenced to the stage recorded at streamgage 03378500 (table 1); the streamgage is on the downstream side of the State Road 66 bridge. The maps cover a range in stage from 10 to 25.4 feet (ft). The 10-ft stage is approximately bankfull and is defined by National Weather Service (2014b) as the "action stage" or that stage which, when reached by a rising stream, requires the NWS or a partner to take some type of mitigation action in preparation for a possible significant hydrologic event. The major flood stage, as determined by the NWS, is $23 \mathrm{ft}$. The 25.42-ft stage is the highest stage on stage-discharge rating curve version 2.0 (updated April 26, 2016). During a recent flood at New Harmony, May 4, 2011, the stage was $23.67 \mathrm{ft}$, the highest recorded stage since 1943 (U.S. Geological Survey, 2014c). Prior to 1943 the highest observed stage was $27.70 \mathrm{ft}$ during the March $1913 \mathrm{flood}$.

\section{Study Area Description}

The Wabash River near the town of New Harmony is in southwest Indiana in the Wabash Lowland physiographic section of the Southern Hills and Lowlands Region (Gray, 2000).
The drainage area is 29,120 square miles $\left(\mathrm{mi}^{2}\right)$ at the upstream end of the study reach, 29,234 $\mathrm{mi}^{2}$ at streamgage 03378500 , and $29,236 \mathrm{mi}^{2}$ at the downstream end of the study reach (U.S. Geological Survey, 2014a, 2014d). The headwaters originate in Randolph County, Ind. (not shown), and the stream flows generally southwestward. As the river passes the northern edge of the town, it is flowing to the southwest. There are no significant tributaries to the Wabash River as it flows through the study reach. Generally, the area has extensive flood plains flanked by broad terraces underlain by outwash sand (Gray, 2000). Bedrock is exposed along the east bank of the river near the downstream extent of the study reach. The bedrock is exposed in the channel during low flows and forms a riffle at moderate flows. The study reach is $3.68 \mathrm{mi}$ long, has an average top-of-bank channel width of about $999 \mathrm{ft}$, and has an average channel slope of 0.0002 (1.06 feet per mile). Most of the land contiguous to the study reach is either in agricultural use or forested with a small portion that is residentially developed.

New Harmony is a historic town on the Wabash River in Posey County, Indiana.

It was established by George Rapp and the Harmony Society in 1814. In 1825, Robert Owen, a Welsh industrialist and social reformer, purchased the town with the intention of creating a new utopian community. While the Owenite social experiment was an economic failure just two years after it began, the community made some important contributions to American society. New Harmony became known as a center for advances in education and scientific research. New Harmony's residents established the first free library, a civic drama club, and a public school system open to men and women. Its prominent citizens included Robert Owen's sons, Indiana congressman and social reformer Robert Dale Owen, who sponsored legislation to create the Smithsonian Institution; David Dale Owen, a noted state and federal geologist; and Richard Owen, state geologist, Indiana University professor, and first president of Purdue University. The town served as the second headquarters of the U.S. Geological Survey and numerous scientists and educators contributed to New Harmony's intellectual community. Many of the old Harmonist buildings still exist and have been restored. Contemporary additions to the town include the Roofless Church and Athenaeum (Boomhower, 2002).

The population of New Harmony has declined in recent years from 916 in 2000 to 789 in 2010 . According to the U.S. Census Bureau, the town has a total area of $0.65 \mathrm{mi}^{2}$, of which $0.64 \mathrm{mi}^{2}$ is land and $0.01 \mathrm{mi}^{2}$ is water (U.S. Census Bureau, 2010). The study area outside of New Harmony is mostly agricultural with forested areas. The main channel and adjacent flood plain within the study reach has one major road crossing, State Road 66 (State Road 14 in Illinois). The State Road 66 bridge is closed to all traffic because of safety concerns. 

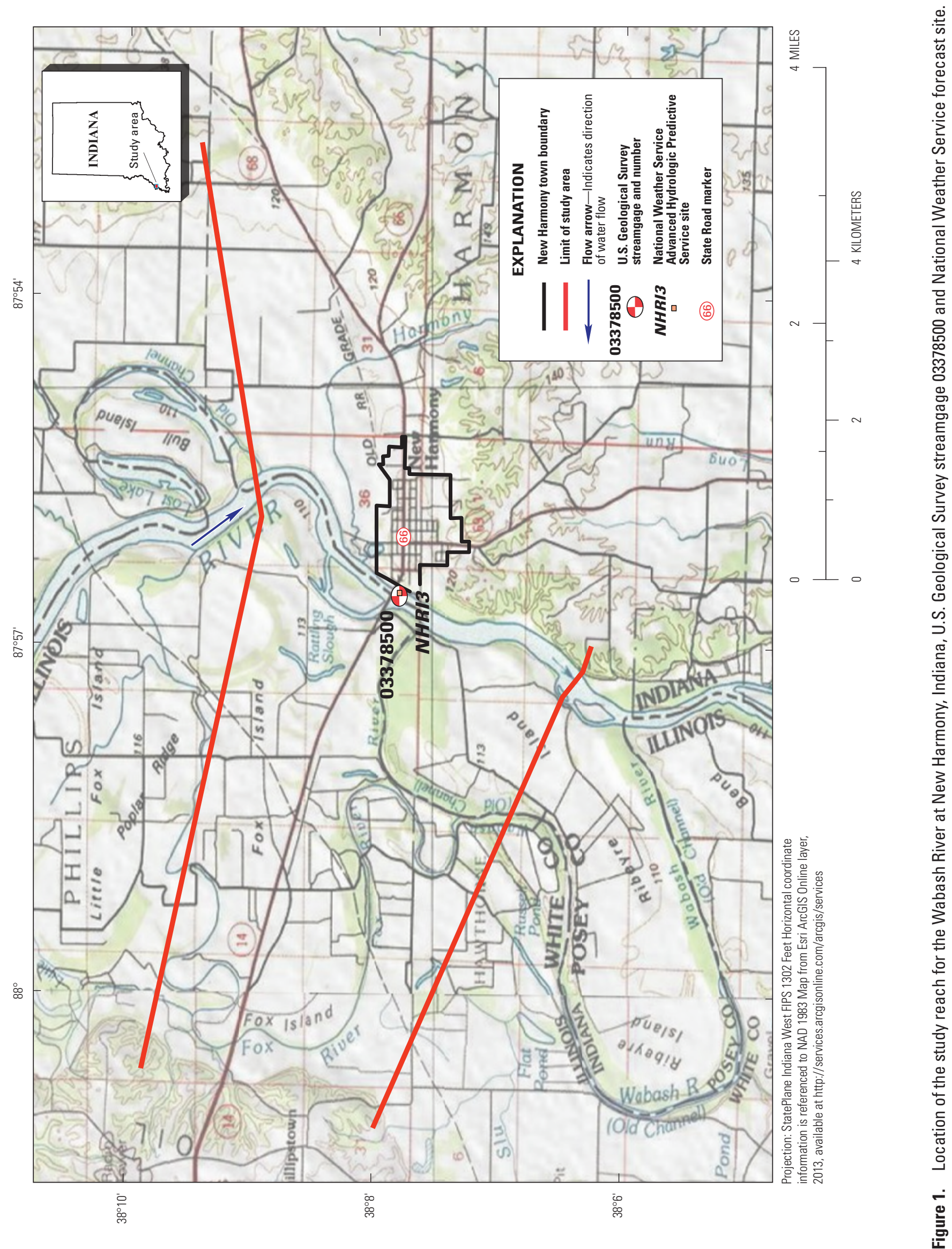


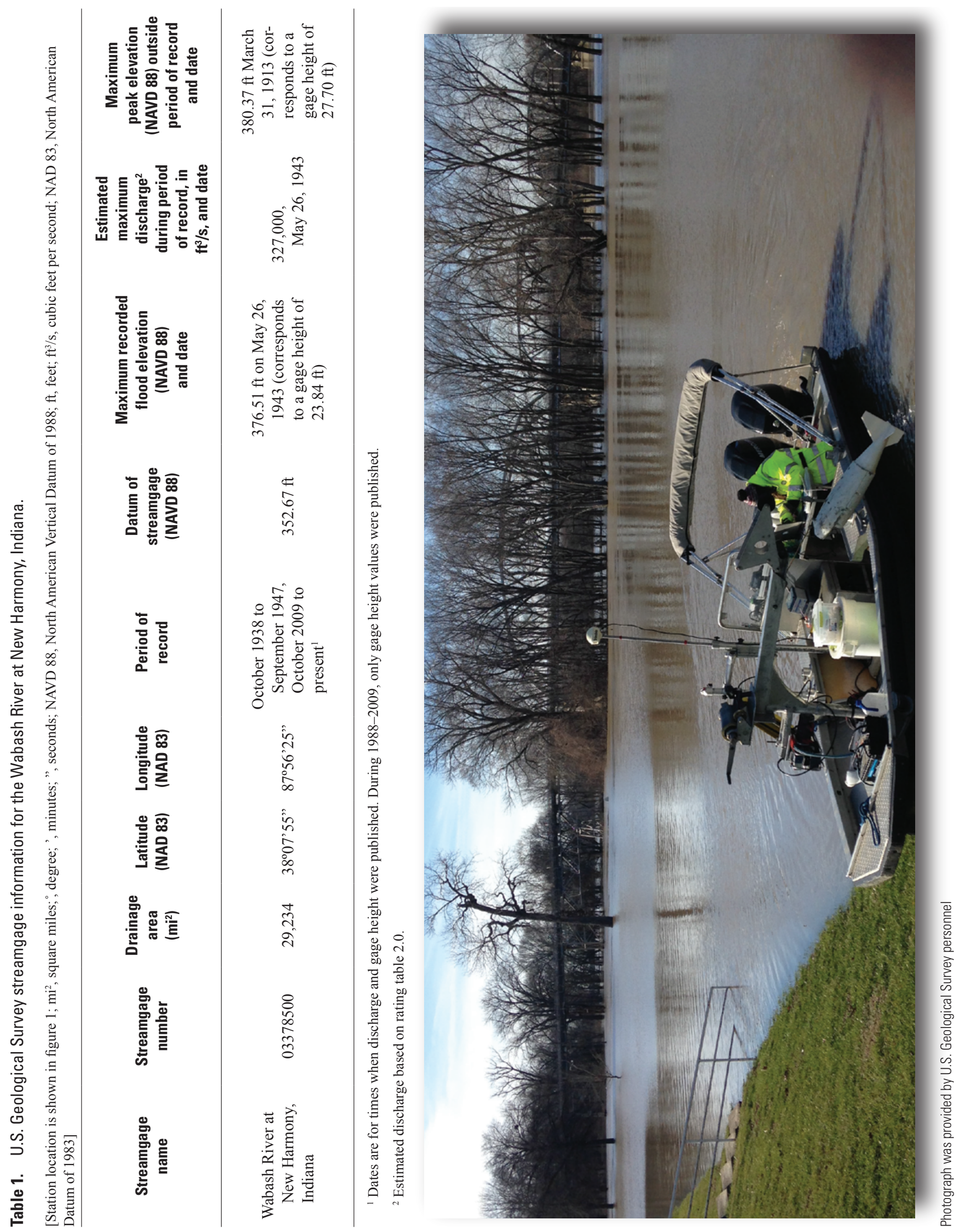




\section{Previous Studies}

The most recent FIS that provides some information for the streamgage at Wabash River at New Harmony is the Preliminary FIS for Posey County (Federal Emergency Management Agency, 2007). The Preliminary FIS investigated the existence and severity of flood hazards in the unincorporated areas of Posey County including the Wabash River, which to a large extent forms the boundary between Indiana and Illinois near New Harmony.

The Indiana Department of Natural Resources (IDNR) has produced Digital Flood Insurance Rate Maps (DFIRM), which include the study area in Posey County (Indiana Department of Natural Resources, 2004). These maps outline the flood hazard areas around New Harmony. In addition, the IDNR, the USGS, Natural Resources Conservation Service, and U.S. Army Corps of Engineers have agreed to the discharge-frequency values for sites along many rivers in Indiana; the values are termed coordinated discharges and assure consistency among the State and Federal agencies that undertake streamflow studies (Indiana Department of Natural Resources, 2014). The coordinated discharges at the 10-, 2-, and 1-percent annual exceedance probabilities for the Wabash River at New Harmony were obtained from StreamStats for Indiana Streams (U.S. Geological Survey, 2014d) and are listed in table 2 .

Table 2. Coordinated discharges for selected annual exceedance probabilities for the Wabash River at New Harmony, Indiana.

$\left[\mathrm{mi}^{2}\right.$, square miles; $\mathrm{ft}^{3} / \mathrm{s}$, cubic feet per second; USGS, U.S. Geological Survey]

\begin{tabular}{lcccc}
\hline $\begin{array}{c}\text { Location on } \\
\text { Wabash River }\end{array}$ & $\begin{array}{c}\text { Drainage } \\
\text { area } \\
\left(\mathbf{m i}^{2}\right)\end{array}$ & \multicolumn{3}{c}{$\begin{array}{c}\text { Coordinated discharges }\left(\mathbf{f t}^{3} / \mathbf{s}\right)^{1,2} \\
\text { for indicated annual exceedance } \\
\text { probabilities (in percent) }\end{array}$} \\
\hline $\begin{array}{c}\text { At USGS } \\
\text { streamgage } \\
\text { number } \\
03378500\end{array}$ & 29,234 & 206,000 & $\mathbf{2}$ & $\mathbf{1}$ \\
\hline
\end{tabular}

'Data from The StreamStats Program (U.S. Geological Survey, 2014d).

${ }^{2}$ Data from Indiana Department of Natural Resources coordinated discharges for the Wabash River (modified) downstream from Mt. Carmel, Illinois.

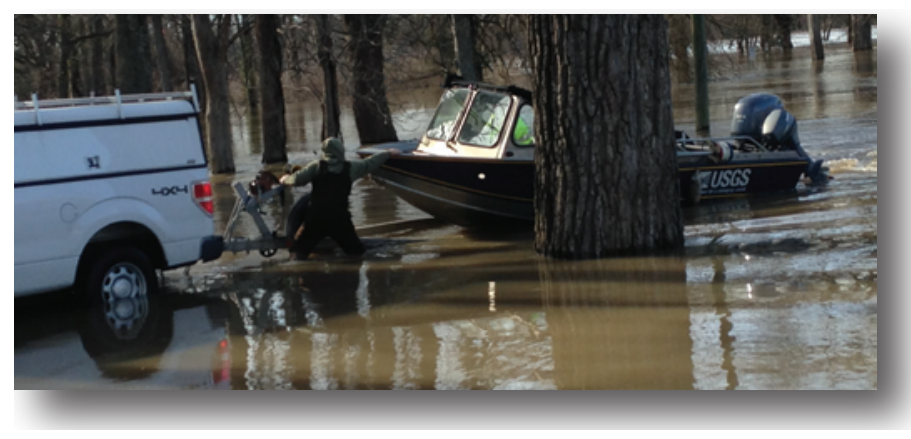

Photograph was provided by U.S. Geological Survey personnel

\section{Creation of Flood-Inundation Map Library}

The USGS has standardized the procedures for creating flood-inundation maps for flood-prone communities so that the process followed and products produced are similar regardless of which USGS office is responsible for the work (U.S. Geological Survey, 2014e). Tasks specific to development of the flood maps for New Harmony, Ind., were (1) collection of topographic and bathymetric data for selected cross sections and geometric data for the Indiana State Road 66 bridge; (2) estimation of energy-loss factors (roughness coefficients) in the stream channel and flood plain and determination of steady-flow data; (3) computation of water-surface profiles using the U.S. Army Corps of Engineers' Hydrologic Engineering Center-River Analysis System (HEC-RAS) computer program (U.S. Army Corps of Engineers, 2010); (4) production of estimated flood-inundation maps at various stream stages using the U.S. Army Corps of Engineers' HECGeoRAS computer program (U.S. Army Corps of Engineers, 2009) and a geographic information system (GIS); and (5) preparation of the maps, both as shapefile polygons that depict the areal extent of flood inundation and as depth grids that provide the depth of floodwaters, for display on a USGS floodinundation mapping application.

\section{Computation of Water-Surface Profiles}

The water-surface profiles used to produce the 17 floodinundation maps in this study were simulated by using HECRAS, version 4.1.0 (U.S. Army Corps of Engineers, 2010). HEC-RAS is a one-dimensional, step-backwater model for simulation of water-surface profiles with gradually varied, steady-state or unsteady-state flow computation options. The HEC-RAS analysis for this study was done using the steadystate (gradually varied) flow computation option.

\section{Hydrologic Data}

The study reach includes one streamgage, 03378500 (fig. 1; table 1), which was in operation from October 1938 to September 1947 and again from October 2009 to the present (2016). During 1988-2009, only gage height was recorded. The streamgage is collocated with the NWS AHPS site NHRI3. Stage is measured every 15 minutes, transmitted hourly by a satellite radio in the streamgage to the USGS database, and made available on the Internet through the USGS National Water Information System (NWIS; U.S. Geological Survey, 2014b). Stage data from this streamgage are referenced to a local datum but can be converted to water-surface elevations referenced to the North American Vertical Datum of 1988 (NAVD 88) by adding $352.67 \mathrm{ft}$. Continuous records of streamflow are computed from a stage-discharge relation, which has been developed for the streamgage, and are available through the USGS NWIS Web site. 
The peak flows used in the model simulations (table 3) were taken from the stage-discharge relation (USGS rating no. 2.0, effective April 26, 2016) for streamgage 03378500 and corresponded with the 17 target stages. All computations used discharge values with known stages from the stage-discharge relation at the gage. No major tributaries join the Wabash River within the 3.68-mi study reach; therefore, the gagederived discharges were not adjusted for tributary inflows but were held constant throughout the study reach for a given profile (table 3).

Table 3. Estimated discharges for corresponding stages and water-surface elevations at U.S. Geological Survey streamgage 03378500 used in the hydraulic model of the Wabash River at New Harmony, Indiana.

[ft, feet; NAVD 88, North American Vertical Datum of 1988; $\mathrm{ft}^{3} / \mathrm{s}$, cubic feet per second; USGS, U.S. Geological Survey]

\begin{tabular}{|c|c|c|}
\hline $\begin{array}{l}\text { Stage of water- } \\
\text { surface profile } \\
\text { (ft) }\end{array}$ & $\begin{array}{l}\text { Water-surface } \\
\text { elevation } \\
\text { (ft, NAVD 88) }\end{array}$ & $\begin{array}{c}\text { Estimated discharge }^{2} \\
\text { at USGS streamgage } \\
\text { number } 03378500 \\
\left(\mathrm{ft}^{3} / \mathrm{s}\right)\end{array}$ \\
\hline 10 & 362.67 & 44,040 \\
\hline 11 & 363.67 & 49,470 \\
\hline 12 & 364.67 & 55,040 \\
\hline 13 & 365.67 & 60,710 \\
\hline 14 & 366.67 & 66,460 \\
\hline 15 & 367.67 & 73,050 \\
\hline 16 & 368.67 & 80,580 \\
\hline 17 & 369.67 & 90,290 \\
\hline 18 & 370.67 & 103,500 \\
\hline 19 & 371.67 & 121,900 \\
\hline 20 & 372.67 & 143,200 \\
\hline 21 & 373.67 & 167,300 \\
\hline 22 & 374.67 & 194,000 \\
\hline 23 & 375.67 & 259,900 \\
\hline 24 & 376.67 & 362,000 \\
\hline 25 & 377.67 & 497,600 \\
\hline 25.42 & 378.09 & 566,600 \\
\hline
\end{tabular}

${ }^{1}$ Water-surface profiles are approximately 1 -foot increments of stage, referenced to the gage datum of the U.S. Geological Survey streamgage, Wabash River at New Harmony, Indiana (station 03378500).

${ }^{2}$ Discharge from USGS rating number 2.0, effective April 26, 2016.

\section{Topographic and Bathymetric Data}

All topographic data used in this study are referenced vertically to NAVD 88 and horizontally to the North American Datum of 1983 (NAD 83). Cross-section elevation data were obtained from a digital elevation model (DEM) that was derived from light detection and ranging (lidar) data that were collected as part of a statewide project during 2011-13 by Woolpert, Inc., Geospatial Services, Dayton, Ohio (Woolpert, Inc., 2011). The lidar data for Posey County Indiana and a small adjacent area in Illinois were collected in 2013. The DEM was obtained from the Indiana Spatial Data Portal (Indiana University, 2013). The original lidar data have a horizontal resolution of $4.9 \mathrm{ft}$ and vertical accuracy of $0.98 \mathrm{ft}$ at a 95-percent confidence level, based on a root mean squared error of $0.49 \mathrm{ft}$ for the "open terrain" land-cover category. By these criteria, the lidar data support production of 2-ft contours (Dewberry, 2012); the final DEM, which was resampled to a grid-cell size of $10 \mathrm{ft}$ by $10 \mathrm{ft}$ to decrease the GIS processing time, has a vertical accuracy of plus or minus $1 \mathrm{ft}$. By using HEC-GeoRAS (a set of procedures, tools, and utilities for processing geospatial data in ArcGIS), elevation data were extracted from the DEM for 36 cross sections. These data subsequently were input to the HEC-RAS model.

Because lidar data cannot provide ground elevations below a stream's water surface, channel cross sections were surveyed by USGS field crews during December 2013. Crosssectional depths were measured by using hydroacoustic instrumentation at 18 locations. A differential global positioning system with real-time kinematic technology was used to derive horizontal locations and the elevation of the water surface at each surveyed cross section.

In the ArcMap application of ArcGIS (Esri, 2014), these field data were used in conjunction with a bathymetry mesh tool, created by Merwade and others (2008), to interpolate below-water ground elevations through the study reach. The density of ground elevations in the mesh was determined using two variables: (1) the number of parallel longitudinal profiles that were evenly spaced across the channel and ran the length of the study reach and (2) the user-specified spacing between cross sections. Ground elevations were either extracted or interpolated from the field data at the intersections of the longitudinal profiles and cross sections that were spaced approximately $500 \mathrm{ft}$ apart. The mesh elevations were subsequently added to the DEM data of the 18 synthetic cross sections before the data were exported to HEC-RAS. Instructions for the bathymetry mesh tool are presented by Merwade (2011).

\section{Hydraulic Structures}

There is one road crossing (State Road 66 in Indiana; State Road 14 in Illinois) that has the potential to affect watersurface elevations during floods along the stream. Bridgegeometry data were obtained from field surveys conducted by USGS personnel for the main bridge over the channel and the four overflow bridges in the flood plain. Because the bridge over the main channel is closed, some measurements and elevations were taken from bridge plans provided by the Federal Highway Administration, Illinois Division (Dan Brydl, Federal Highway Administration, Illinois Division, written commun., 2015). The surveyed bridge openings are all on State Road 66 (State Road 14 in Illinois). There are discontinuous earthen embankments along the river on the west bank (Illinois side). 
Because of the uncertainty as to the effectiveness of these embankments, they were not simulated as levees in the HECRAS model; rather, where appropriate to do so, the landward sides of the embankments were simulated as ineffective flow areas up to the elevation of the top of the embankment.

\section{Energy-Loss Factors}

Hydraulic analyses require the estimation of energy losses that result from frictional resistance exerted by a channel on flow. These energy losses are quantified by the Manning's roughness coefficient ( $n$-value) (Arcement and Schneider, 1989). Initial (precalibration) $n$-values were selected on the basis of field observations and high-resolution aerial photographs. An $n$-value of 0.03 was selected for the main channel since it is natural, is fairly clean (free of obstructions), and has a low gradient. An $n$-value of 0.08 was used for the overbank areas, which are dominated by agricultural fields and forest in the rural sections of the study reach, and the residential area of New Harmony to the east of the river.

The initial $n$-values were adjusted as part of the calibration process, which involved minimizing the differences between simulated and observed water-surface elevations at the streamgage and elsewhere along the study reach. Roughness-coefficient adjustment factors were varied by flow and adjusted until the simulated water-surface elevations approximated the 17 target water-surface elevations. The actual $n$-values were computed by multiplying the initial $n$-value by each of the roughness-coefficient adjustment factors. Main channel $n$-values ranged from 0.023 to 0.044 , and overbank values ranged from 0.048 to 0.144 .

\section{Hydraulic Model}

The HEC-RAS analysis for this study was done by using the steady-state flow computation option. Steady-state flow data consisted of flow regime, boundary conditions, and peak flows that produced water-surface elevations at the streamgage cross sections that matched target water-surface elevations within $0.35 \mathrm{ft}$ of the current rating for streamgage 03378500 . These target elevations coincided with even 1 -ft increments of stage, referenced to the local streamgage datum. Subcritical (tranquil) flow regime was assumed for the simulations. Normal depth, based on an estimated average channel slope of 0.0002 from data obtained from a USGS field crew in 2013, was used as the downstream boundary condition of the reach. The peak flows that were used in the model were discussed in the "Hydrologic Data" section.

The hydraulic model was calibrated to the most current stage-discharge relation at the Wabash River streamgage and to the documented high-water marks from the flood of April 2013. Model calibration was accomplished by adjusting Manning's $n$-values until the results of the hydraulic computations closely agreed with the observed water-surface elevations for given flows. Differences between target and simulated watersurface elevations for the 17 simulated flows at the USGS streamgage were equal to or less than $0.35 \mathrm{ft}$ (table 4). Differences between surveyed and simulated elevations of high water-surface marks from the flood of April 27-28, 2013, were equal to or less than $1.45 \mathrm{ft}$ (fig. 2, table 5). Six of the eight surveyed elevations differ from simulated elevations by $0.35 \mathrm{ft}$ or less. The results demonstrate that the model is capable of simulating accurate water levels over a wide range of flows in the basin.

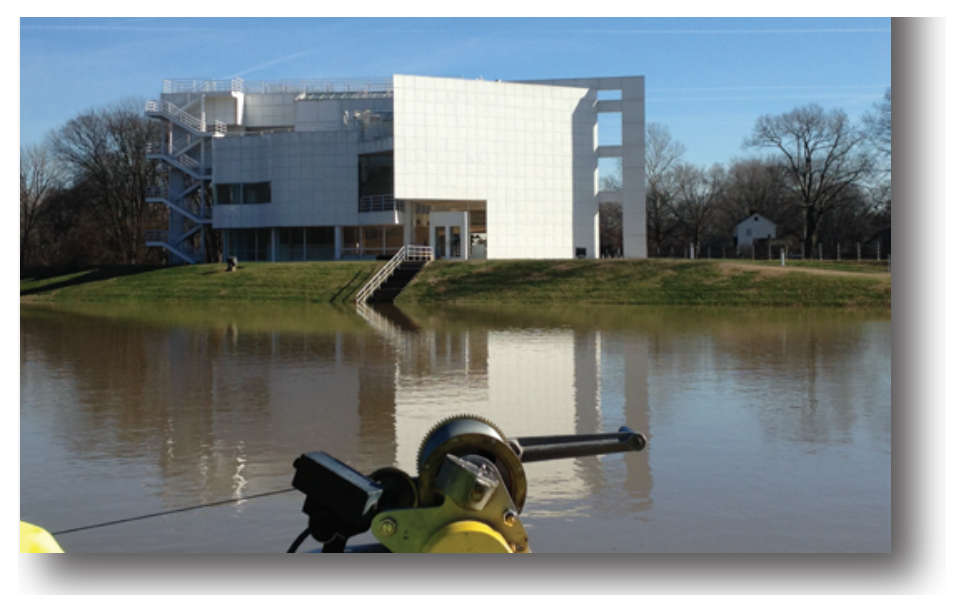

Flooding near New Harmony's Athenaeum (Photo provided by U.S. Geological Survey personnel)

Table 4. Calibration of hydraulic model to target water-surface elevations at the U.S. Geological Survey streamgage on the Wabash River at New Harmony, Indiana (station 03378500).

[ft, feet; NAVD 88, North American Vertical Datum of 1988]

\begin{tabular}{cccc}
\hline $\begin{array}{c}\text { Stage of water- } \\
\text { surface profile } \\
\text { (ft) }\end{array}$ & $\begin{array}{c}\text { Target } \\
\text { water-surface } \\
\text { elevation } \\
\text { (ft, NAVD 88) }\end{array}$ & $\begin{array}{c}\text { Simulated } \\
\text { water-surface } \\
\text { elevation } \\
\text { (ft, NAVD 88) }\end{array}$ & $\begin{array}{c}\text { Elevation } \\
\text { difference } \\
\text { (ft) }\end{array}$ \\
\hline 10.00 & 362.67 & 362.58 & -0.09 \\
\hline 11.00 & 363.67 & 363.39 & -0.28 \\
\hline 12.00 & 364.67 & 364.86 & 0.19 \\
\hline 13.00 & 365.67 & 365.95 & 0.28 \\
\hline 14.00 & 366.67 & 366.65 & -0.02 \\
\hline 15.00 & 367.67 & 367.50 & -0.17 \\
\hline 16.00 & 368.67 & 368.38 & -0.29 \\
\hline 17.00 & 369.67 & 369.32 & -0.35 \\
\hline 18.00 & 370.67 & 370.37 & -0.30 \\
\hline 19.00 & 371.67 & 371.39 & -0.28 \\
\hline 20.00 & 372.67 & 372.41 & -0.26 \\
\hline 21.00 & 373.67 & 373.49 & -0.18 \\
\hline 22.00 & 374.67 & 374.51 & -0.16 \\
\hline 23.00 & 375.67 & 375.47 & -0.20 \\
\hline 24.00 & 376.67 & 376.83 & 0.16 \\
\hline 25.00 & 377.67 & 377.43 & -0.24 \\
\hline 25.42 & 378.09 & 378.18 & 0.09 \\
\hline
\end{tabular}




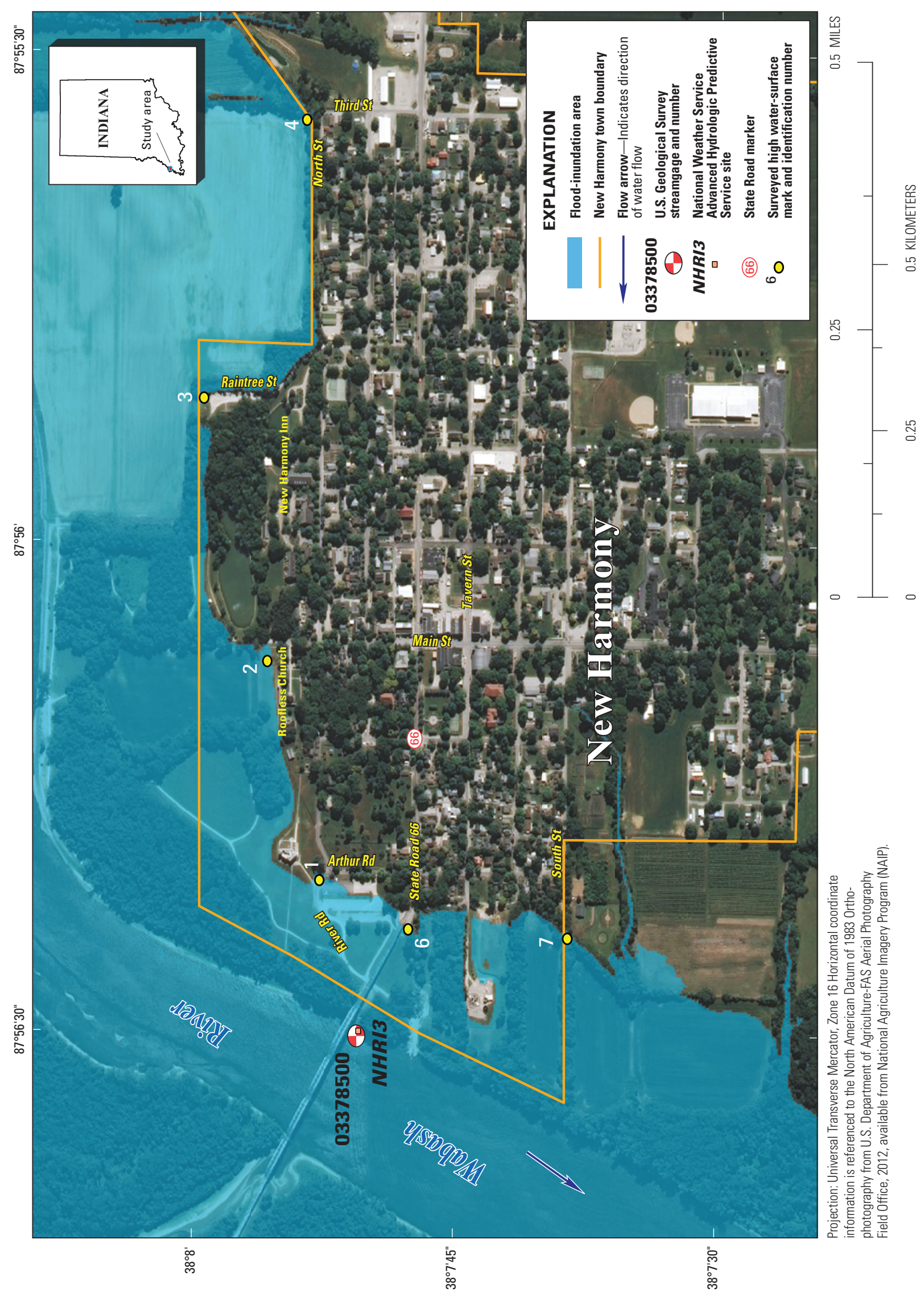

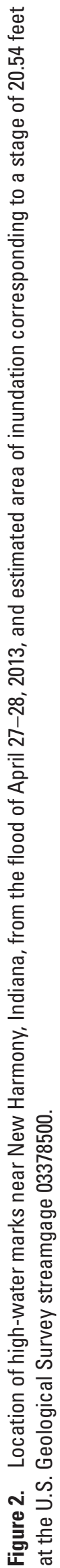


Table 5. Calibration of hydraulic model to water-surface elevations at selected locations along the Wabash River, New Harmony, Indiana, for the flood of April 27-28, 2013.

[ft, feet; NAVD 88, North American Vertical Datum of 1988; N, north]

\begin{tabular}{|c|c|c|c|c|}
\hline Location & $\begin{array}{c}\text { High } \\
\text { water-surface } \\
\text { mark field } \\
\text { identification } \\
\text { number }^{1}\end{array}$ & $\begin{array}{c}\text { Surveyed high } \\
\text { water-surface } \\
\text { mark elevation } \\
\text { (ft, NAVD 88) }\end{array}$ & $\begin{array}{l}\text { Modeled } \\
\text { water-surface } \\
\text { elevation } \\
\text { (ft, NAVD 88) }\end{array}$ & $\begin{array}{l}\text { Elevation } \\
\text { difference }\end{array}$ \\
\hline $\begin{array}{l}\text { At northeast edge of parking lot } \\
\text { that is south of River Road and } \\
\text { East of Arthur Street }\end{array}$ & 1 & 373.23 & 373.36 & 0.13 \\
\hline $\begin{array}{l}\text { In field northeast of the Roofless } \\
\text { Church, (architectural site) }\end{array}$ & 2 & 373.55 & 373.49 & -0.06 \\
\hline $\begin{array}{l}\text { On Raintree Street northeast of } \\
\text { the New Harmony Inn }\end{array}$ & 3 & 374.48 & 373.63 & -0.85 \\
\hline $\begin{array}{l}\text { Near the corner of Third and } \\
\text { North Street }\end{array}$ & 4 & 375.11 & 373.66 & -1.45 \\
\hline $\begin{array}{l}\text { West side of Griffin Road, } 0.8 \\
\text { miles north of the intersection } \\
\text { of State Road } 66 \text { (Not shown in } \\
\text { figure 2) }\end{array}$ & 5 & 373.69 & 373.90 & 0.21 \\
\hline Near the west end of South Street & 7 & 373.00 & 373.05 & 0.05 \\
\hline $\begin{array}{l}\text { On Old Dam Road, approximately } \\
370 \mathrm{ft} \text { north of the intersection } \\
\text { with County Road } 435 \mathrm{~N}, 1.8 \\
\text { miles southwest of New Har- } \\
\text { mony (Not shown in figure 2) }\end{array}$ & 8 & 371.16 & ${ }^{2} 370.81$ & -0.35 \\
\hline
\end{tabular}

${ }^{1}$ U.S.Geological Survey field survey of high water-surface marks for the flood of April 27-28, 2013, collected April 27, 2013, on the rising limb of the hydrograph.

${ }^{2}$ Elevation extrapolated from model profile. 


\section{Development of Water-Surface Profiles}

The calibrated hydraulic model was used to generate water-surface profiles for 16 stages at $1-\mathrm{ft}$ intervals from $10 \mathrm{ft}$ to $25 \mathrm{ft}$ plus a profile at $25.42 \mathrm{ft}$ (highest stage on rating 2.0) as referenced to the local datum of the Wabash River streamgage (352.67 ft NAVD 88). These stages correspond to elevations from $362.67 \mathrm{ft}$ to $378.09 \mathrm{ft}$ NAVD 88 .

\section{Development of Flood-Inundation Maps}

Flood-inundation maps were created for a reach of the Wabash River at New Harmony, Ind. The maps were created in a GIS by combining the 17 water-surface profiles and DEM data. The DEM data were derived from the same lidar data described previously in the "Topographic and Bathymetric Data" section and therefore have an estimated vertical accuracy of $2 \mathrm{ft}$ (that is, plus or minus $1 \mathrm{ft}$ ). Estimated flood-inundation boundaries for each simulated profile were developed with HEC-GeoRAS software (U.S. Army Corps of Engineers, 2009), which allows the preparation of geometric data for import into HEC-RAS and processes simulation results exported from HEC-RAS (U.S. Army Corps of Engineers, 2010). Shapefile polygons and depth grids of the inundated areas for each profile were modified, as required, in the ArcMap application of ArcGIS (Esri, 2014) to ensure a hydraulically reasonable transition of the flood boundaries between modeled cross sections.

Any inundated areas that were detached from the main channel were examined to identify subsurface connections with the main river, such as through culverts under roadways. Where such connections existed, the mapped inundated areas were retained in their respective flood maps; otherwise, the erroneously delineated parts of the flood extent were deleted.

Because of the limited extent of the study area, it may appear that some areas of the flood plain that are somewhat remote from the main channel are included in the inundation area. Much of the western side of the study area is inundated because the river channel bends to the west both upstream and downstream from New Harmony. When flow leaves the channel upstream from New Harmony, the channel configuration allows for flow to spread far into the western flood plain and to meet the main channel downstream where the river channel again bends to the west (fig. 3). A stage of $17 \mathrm{ft}$ was chosen for figure 3 because it is an intermediate stage and demonstrates that even areas that appear isolated are in fact carrying flow. In addition to the bends in the main channel, there are oxbows [shown in fig. 1 as Wabash River (Old Channel)], sloughs, and discontinuous earthen embankments that allow flow into the flood plain on the western side of the river.

The flood-inundation areas are overlaid on high-resolution, georeferenced, aerial photographs of the study area. Bridge surfaces are displayed as inundated regardless of the actual water-surface elevation in relation to the lowest structural chord of the bridge or the bridge deck.

Estimates of water depth can be obtained from the depthgrid data that are included with the presentation of the flood maps on an interactive USGS mapping application described in the following section, "Flood-Inundation Map Delivery." The flood-inundation map corresponding to the highest simulated water-surface profile, a stage of $25.4 \mathrm{ft}$, is presented in figure 4.

\section{Flood-Inundation Map Delivery}

The current study documentation is available online at the USGS Publications Warehouse (http://pubs.usgs.gov/ sir/2016/5119). Also, a Flood Inundation Mapping Science Web site at http://water.usgs.gov/osw/flood_inundation (U.S. Geological Survey, 2014e) has been established to make USGS flood-inundation study information available to the public; the site links to a mapping application that presents map libraries and provides detailed information on flood extents and depths for modeled sites. The mapping application enables the production of customized flood-inundation maps from the map library for Wabash River at New Harmony, Ind. A link on this Web site connects to the USGS NWIS (U.S. Geological Survey, 2014a), which presents the current stage and streamflow at USGS streamgage 03378500 to which the flood-inundation maps are referenced. A second link connects to the NWS Advanced Hydrologic Prediction Service (AHPS) site (National Weather Service, 2014a) so that the user can obtain applicable information on forecasted peak stage. The estimated flood-inundation maps are displayed in sufficient detail so that preparations for flooding and decisions for emergency response can be performed efficiently. Depending on the flood magnitude, roadways are shown as shaded (inundated and likely impassable) or not shaded (dry and passable) to facilitate emergency planning and use. Bridges are shaded - that is, shown as inundated - regardless of the flood magnitude. A shaded building should not be interpreted to indicate that the structure is completely submerged, rather that bare earth surfaces in the vicinity of the building are inundated. In these instances, the water depth (as indicated in the mapping application by holding the cursor over an inundated area) near the building would be an estimate of the water level inside the structure, unless flood-proofing measures had been implemented.

\section{Disclaimer for Flood-Inundation Maps}

The flood-inundation maps should not be used for navigation, regulatory, permitting, or other legal purposes. The USGS provides these maps "as is" for a quick reference, emergency planning tool but assumes no legal liability or responsibility resulting from the use of this information. 


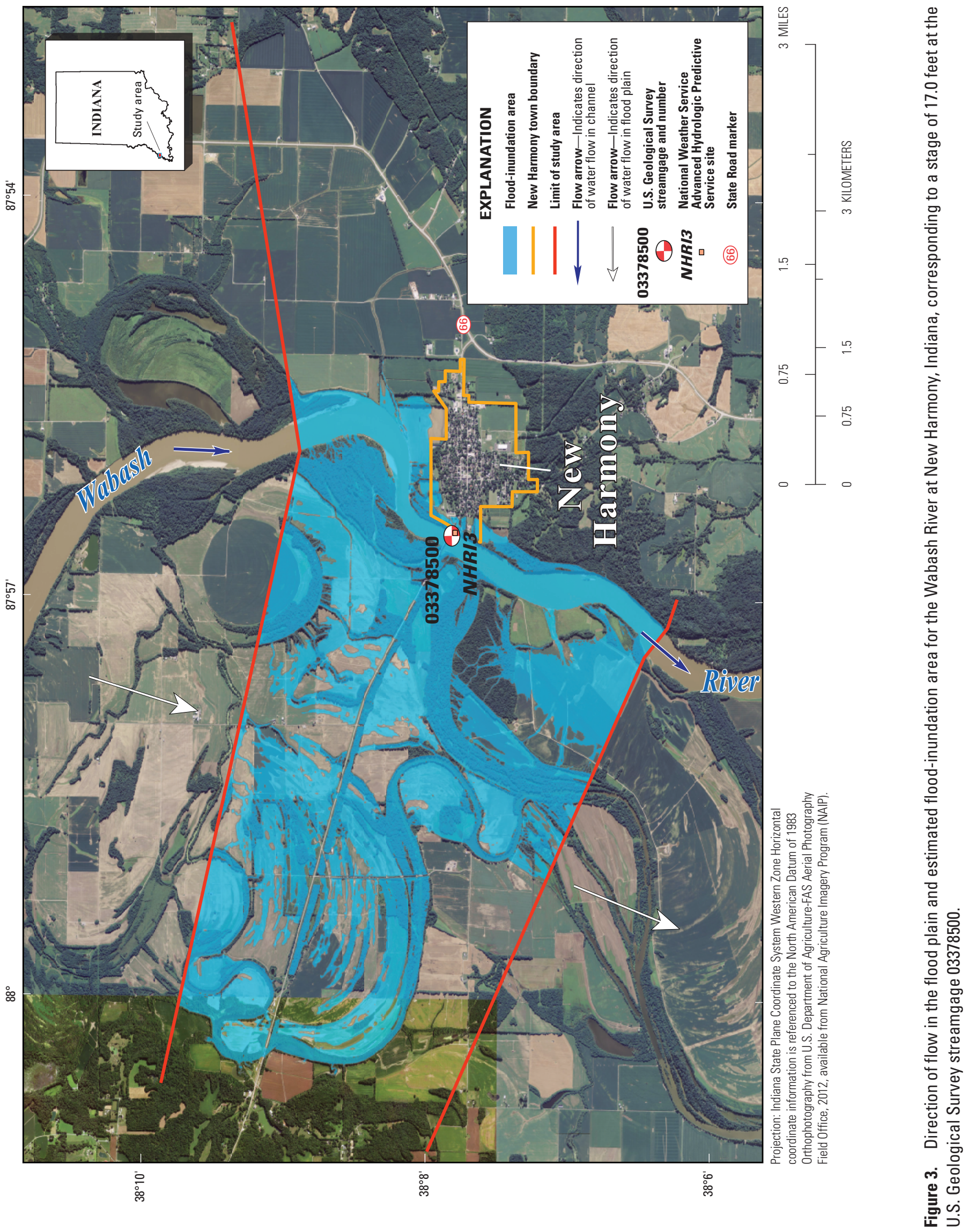




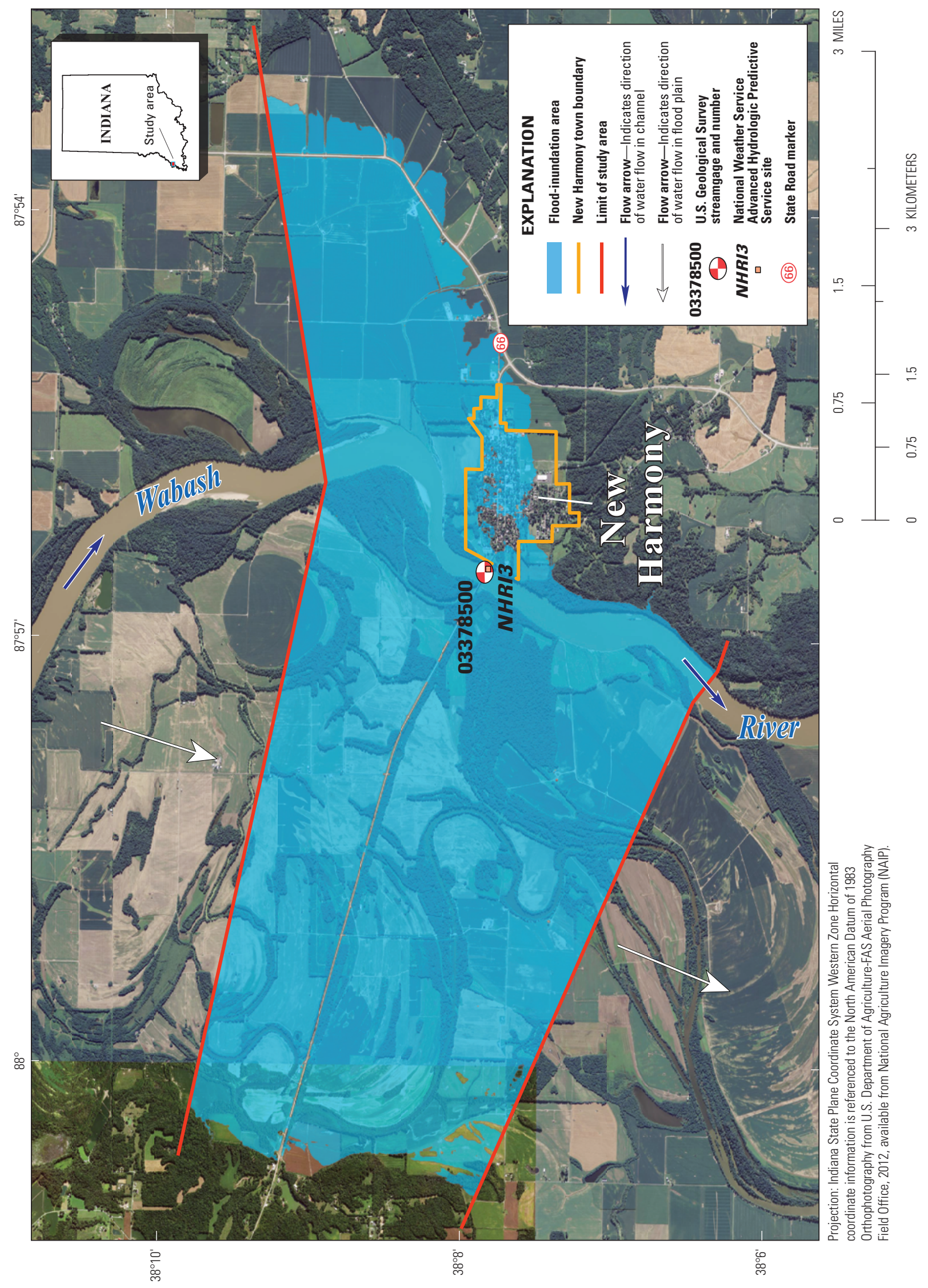

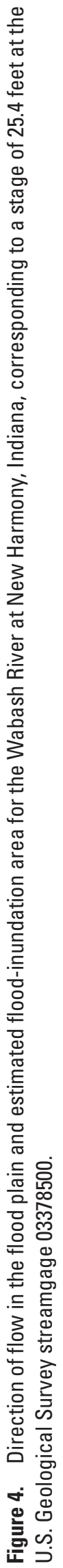




\section{Uncertainties and Limitations Regarding Use of Flood-Inundation Maps}

Although the flood-inundation maps represent the boundaries of inundated areas with a distinct line, some uncertainty is associated with these maps. The flood boundaries shown were estimated on the basis of water stages and streamflows at a selected USGS streamgage. Water-surface elevations along the stream reaches were estimated by steady-state hydraulic modeling, assuming unobstructed flow, and using streamflows and hydrologic conditions anticipated at the USGS streamgage. The hydraulic model reflects the land-cover characteristics and any bridge, embankment, or other hydraulic structures existing as of December 2013. Unique meteorological factors (timing and distribution of precipitation) may cause actual streamflows along the modeled reach to vary from those assumed during a flood, which may lead to deviations in the water-surface elevations and inundation boundaries shown. Additional areas may be flooded because of unanticipated conditions such as changes in the streambed elevation or roughness, backwater into tributaries along a main stem river, or backwater from localized debris or ice jams. The accuracy of the floodwater extent portrayed on these maps will vary with the accuracy of the DEM used to simulate the land surface.

If this series of flood-inundation maps will be used in conjunction with NWS river forecasts, the user should be aware of additional uncertainties that may be inherent or factored into NWS forecast procedures. The NWS uses forecast models to estimate the quantity and timing of water flowing through selected stream reaches in the United States. These forecast models (1) estimate the amount of runoff generated by precipitation and snowmelt, (2) simulate the movement of floodwater as it proceeds downstream, and (3) predict the flow and stage (and water-surface elevation) for the stream at a given location (AHPS forecast point) throughout the forecast period (every 6 hours and 3 to 5 days in the future in many locations). For more information on AHPS forecasts, please refer to http://water.weather.gov/ahps/forecasts.php. Additional uncertainties and limitations pertinent to this study may be described elsewhere in this report.

\section{Summary}

A series of 17 digital flood-inundation maps were developed in cooperation with the Indiana Office of Community and Rural Affairs for the Wabash River at New Harmony, Indiana, from 1.77 miles (mi) upstream to $1.91 \mathrm{mi}$ downstream from U.S. Geological Survey (USGS) streamgage 03378500 at the State Road 66 bridge. The maps were developed by using the U.S. Army Corps of Engineers' Hydraulic Engineering Center-River Analysis System HEC-RAS and HEC-GeoRAS programs to compute water-surface profiles and to delineate estimated flood-inundation areas and depths of flooding for selected stream stages. The HEC-RAS hydraulic model was calibrated to the current stage-discharge relation at the Wabash River streamgage at New Harmony (03378500) and to the high water-surface marks from the flood of April 27-28, 2013. The model was used to compute 17 water-surface profiles for flood stages at approximately 1 -foot (ft) intervals referenced to the streamgage datum and ranging from $10 \mathrm{ft}$, or near bankfull, to $25.4 \mathrm{ft}$, which is the highest stage of the stage-discharge rating. The simulated water-surface profiles were then combined with a geographic information system digital elevation model derived from light detection and ranging (lidar) data to delineate estimated flood-inundation areas as shapefile polygons and depth grids for each profile. These flood-inundation polygons were overlaid on high-resolution, georeferenced, aerial photographs of the study area. The flood maps are available through a mapping application that can be accessed on the USGS Flood Inundation Mapping Science Web site (http:// water.usgs.gov/osw/flood_inundation).

Interactive use of the maps on the USGS mapping application can give users a general indication of depth of water at any point by using the mouse cursor to click within the shaded areas. The mapping application enables the production of customized flood-inundation maps from the map library for Wabash River at New Harmony, Ind. These maps, in conjunction with the real-time stage data from the USGS streamgage, Wabash River at New Harmony, Ind. (station 03378500), and forecasted flood stage data from the National Weather Service Advanced Hydrologic Prediction Service will help to guide the general public in taking individual safety precautions and will provide emergency management personnel with a tool to efficiently manage emergency flood operations and post-flood recovery efforts.

\section{References Cited}

Arcement, G.J., and Schneider, V.R., 1989, Guide for selecting Manning's roughness coefficients for natural channels and flood plains: U.S. Geological Survey Water-Supply Paper $2339,38 \mathrm{p}$.

Boomhower, Ray E., 2002, New Harmony: Home to Indiana's Communal Societies: Traces of Indiana and Midwestern History, v. 14, no. 4, 36-37.

Dewberry, 2012, National enhanced elevation assessment: Fairfax, Va., 84 p., accessed July 14, 2014, at http://www. dewberry.com/services/geospatial/national-enhanced-elevation-assessment.

Esri, 2014, ArcGIS, accessed July 2014 at http://www.esri. com/software/arcgis/.

Federal Emergency Management Agency, 2007, Preliminary Flood Insurance Study, Posey County, Indiana, and unincorporated areas: Washington, D.C., 21 p., 3 pls., accessed May 13, 2015, at http://www.in.gov/dnr/water/files/posey-fis.pdf. 
Gray, H.H., 2000, Physiographic divisions of Indiana: Bloomington, Ind., Indiana Geological Survey Special Report 61, 15 p., 1 pl.

Indiana Department of Natural Resources, 2004, DFIRM database: New Harmony, Ind., accessed July 2014 at http:// www.in.gov/dnr/water/6669.htm.

Indiana Department of Natural Resources, 2014, Coordinated discharges of selected streams in Indiana, accessed January 2015 at http://www.in.gov/dnr/water/4898.htm.

Indiana University, 2013, Indiana spatial data portal, accessed March 2015 at http://gis.iu.edu/.

Merwade, Venkatesh, 2011, Creating river bathymetry mesh from cross-sections: Purdue University, School of Civil Engineering, accessed March 2013 at http://web.ics.purdue. edu/ vmerwade/research/bathymetry_tutorial.pdf.

Merwade, Venkatesh, Cook, Aaron, and Coonrod, Julie, 2008 GIS techniques for creating river terrain models for hydrodynamic modeling and flood inundation mapping: Environmental Modelling and Software, v. 23, no. 10-11, p. 1300-1311.

National Weather Service, 2014a, Advanced hydrologic prediction service, Wabash River at New Harmony, Indiana (NHRI3), accessed May 2015 at http://water.weather.gov/ ahps $2 /$ hydrograph.php?wfo=pah\&gage $=$ nhri3 .

National Weather Service, 2014b, National Weather Service glossary, accessed June 2014 at http://w1.weather.gov/glossary/index.php?word=action + stage.

U.S. Army Corps of Engineers, Hydrologic Engineering Center, 2009, HEC-GeoRAS, GIS tools for support of HEC-RAS using ArcGIS, user's manual [variously paged], accessed June 2014 at http://www.hec.usace.army.mil/software/hec-georas/documentation/HEC-GeoRAS_43_Users Manual.pdf.
U.S. Army Corps of Engineers, Hydrologic Engineering Center, 2010, HEC-RAS river analysis system, hydraulic reference manual (ver. 4.1) [variously paged], accessed June 2014 at http://www.hec.usace.army.mil/software/hec-ras/ documentation/HEC-RAS_4.1_Reference_Manual.pdf.

U.S. Census Bureau, 2010, 2010 Census interactive population search IN-New Harmony town: Washington, D.C., accessed December 2014 at http:/www.census.gov/2010census/popmap/ipmtext.php?fl=18.

U.S. Geological Survey, 2014a, USGS 03378500, Wabash River at New Harmony, Indiana: U.S. Geological Survey, accessed December 2014 at http://nwis.waterdata.usgs.gov/ in/nwis/uv?site_no $=03378500$.

U.S. Geological Survey, 2014b, USGS surface-water data for the Nation: U.S. Geological Survey, accessed December 2014 at http://nwis.waterdata.usgs.gov/in/nwis/ nwisman/?site_no=03378500\&agency_cd=USGS.

U.S. Geological Survey, 2014c, USGS 03378500, Wabash River at New Harmony, Indiana: U.S. Geological Survey, accessed December 2014 at http://nwis.waterdata. usgs.gov/in/nwis/peak?site_no $=03378500 \&$ agency $\mathrm{cd}=\mathrm{USGS} \&$ format $=\mathrm{html}$.

U.S. Geological Survey, 2014d, StreamStats for Indiana streams, accessed April 2015 at http://streamstats.usgs.gov/ indiana.html.

U.S. Geological Survey, 2014e, USGS Flood inundation mapping science: U.S. Geological Survey, accessed March 2015 at http://water.usgs.gov/osw/flood_inundation.

Woolpert, Inc., 2011, Woolpert Order No. 71177, Indiana Statewide Imagery and LiDAR Program, remote sensing image: Dayton, Ohio, Woolpert, Inc., metadata accessed January 21, 2015, at http://gis.iu.edu/files/documents/ in2011_ortho.txt. 
Publishing support provided by the

U.S. Geological Survey Science Publishing Network, West Trenton Publishing Service Center

For more information concerning the research in this report, contact: Director, Indiana Water Science Center

U.S. Geological Survey

5957 Lakeside Boulevard, Indianapolis,

IN 46278-1996

http://in.water.usgs.gov/ 
